\title{
Development Strategy of Surowiti Hill Religious Tourism in Panceng Subdistrict, Gresik
}

\author{
1Tisa Angelia, 2Eddy Imam Santoso \\ 1,2Merdeka University of Surabaya, Surabaya, Indonesia \\ 1tisaangelia78@gmail.com, 2heddyimas@gmail.com
}

\begin{tabular}{|c|c|}
\hline Article Info & stract \\
\hline $\begin{array}{l}\text { Article History } \\
\text { Received: July 12, } 2018 \\
\text { Accepted: September 30, } \\
2018\end{array}$ & \multirow{2}{*}{$\begin{array}{l}\text { Religious tourism has spread to several areas in Gresik, East Java, and has } \\
\text { potentially increased local revenue. Religious tourist objects include wali } \\
\text { tourism and some other religious objects. Sunan Giri and Maulana Malik } \\
\text { Ibrahim tourist sites are two religious objects frequently visited by many } \\
\text { tourists and make the city of Gresik known as Wali Tourist City. Surowiti Hill } \\
\text { site is one of the attractions in Gresik which consists of religious sites in the } \\
\text { form of tombs and stopover Islamic religious leaders, as well as natural } \\
\text { attraction in the form of caves. This research aims to determine the potential } \\
\text { of Surowiti Hill Tourism and further formulate the development strategy as } \\
\text { religious tourism. This research used exploratory method with SWOT } \\
\text { analysis technique. The analysis reveals that the strengths and opportunities } \\
\text { of the site lies on its natural destinations, such as Jamur Hill and Dalegan } \\
\text { Beach, and the existence of religious sites already well known as Sunan Giri } \\
\text { and Maulana Malik Ibrahim. The site's weakness includes sanitary } \\
\text { conditions, provision of clean water, and access to the destination. Threat } \\
\text { factor includes the lack of support from community and government and the } \\
\text { rapid development of other industries that might contaminate the nature. In } \\
\text { sum, the development of Surowiti Hill site has not been optimal in terms of } \\
\text { management and promotion. }\end{array}$} \\
\hline $\begin{array}{l}\text { Keywords } \\
\text { Surowiti Hill; Development } \\
\text { Strategy; Religious Tourism; } \\
\text { Exploratory }\end{array}$ & \\
\hline & \\
\hline
\end{tabular}

\section{INTRODUCTION}

Today's world tourism development sees dominant shifts in western countries as producers of international tourists. This trend is obvious when one notes the rapid tourism development in Pacific Asia, the Middle East and CIS countries (Cetin \& Dincer, 2016). The escalation in the number of Moslem tourists has promoted the birth of sharia concept as part of halal tourism in some countries including Indonesia. As a Muslim majority country, Indonesia has a great opportunity to develop Islamic tourism that respects the cultural and Islamic values (Barat, 2015). The development of tourism in Indonesia shows halal tourism is increasingly familiar among Muslim travelers, so that various regions in the archipelago increasingly develop the concept of tourism (Hadi \& al-Asy Ari, 2017).

The development of religious tourism cannot be separated from the application of the concept of halal tourism that is now also increasingly shows its ability to increase the country's foreign exchange and improve the economy of the community, especially the income of the community around the tourist site (Battour \& Ismail, 2016). Religious tourism is a type of tourism that has the purpose of meeting the spiritual needs of human beings in strengthening the faith by visiting places that are considered to have a religious value (Anwar, Hamid, Administrasi, \& Malang, 2017). 
Tourism is famous in Indonesia, and it is predicted that by 2019 the tourism sector will become Indonesia's main source of foreign exchange (Mahasiswa et al., n.d.). As one of the world's tourist destinations known with its religious tourism, Indonesia has several regions that apply the concept of halal tourism, for example West Sumatra, Riau, Lampung, Banten, Jakarta, West Java, East Java, Makassar, and Lombok (Asdhiana in Suherlan, 2015). Gresik Regency located in East Java Province is one of the areas known for its religious tourism, where a number of pesantren and some religious tourism attractions are available.

Famous religious tourist destinations in Gresik Regency include Sunan Giri and Maulana Malik Ibrahim Graves, and Surowiti Hill, where Sunan Kalijaga Stopovers and tombs of some Islamic leaders are located. These religious sites are also supported with natural tours and caves. Surowiti Hill complex itself is a high potential destination to be developed due to its proximity to Mushroom Hill and Dalegan white sandy beach. This tourism zone has breathtaking natural views including steep, hilly sites. Surowiti Hill Tourism with its various tourist destinations has special appeal for tourists, as seen from the increasing number of visitors each year. In 2008 there were 4,814 tourists visiting the destinations, 6,540 visitors in 2009, 14,890 in 2010, and 18,780 in 2011 (Syafik, 2012). Nevertheless, visitor distribution in each destination is limping, which results in poor development of tourist destinations in Surowiti Hill.

Religious tourism with its appealing halal tourism concept is very important and strategic because this sector is a reliable to boost the welfare of communities around the tourist destinations. This is made possible through its potentials in involving the community's participation, especially in improving tourism in Gresik (Arief, 2016). Community's participation is a positive contribution in developing tourism. Local community contribution will help maintain existing resources and propel selling value of the area and its investment (Fandeli, 2001). To optimize Surowiti Hill's potential as a religious and natural tourist destination there has to be a study to recognize its potentials, problems, and continuous management strategy. In addition, the strategic value of a religious tourist destination in giving benefits to surrounding community has to be acknowledged, one of which through developing religious tourism by way of preservation, community empowerment process and well-integrated recreation activities.

\section{METHOD}

There are two sources of data analyzed in this research, primary data and secondary data. In collecting primary data, field observation (direct observation) method was used. A detail observation guideline was prepared as well as a check list table which was also used as observation guideline (Supriharjo, 2013: III-3).

Secondary data were collected by way of literature review and documentary search. Literature review focused on some previous study results on religious tourism management and development of Surowiti Hill tourism in Panceng sub district. Other data were collected through questionnaires and a series of interviews.

The result of tourism potential identification was then integrated with respondent perception and participation to support strategy alternative in developing religious tourism. The result was then analyzed in terms of its Strength, Weakness, Opportunity, and Threat (SWOT) (Rangkuti, 2005) by analyzing internal and external factors of Surowiti Hill religious tourism. SWOT analysis was considered useful in determining alternative strategies to develop Surowiti Hill religious tourism in Panceng Subdistrict, Gresik. 


\section{RESULT}

\section{Current Condition of Potential Tourism in Gresik Regency}

Gresik is an industrial city that keeps developing. Factories and warehouses keep expanding towards suburbs, including Kawasan Industri Gresik (KIG - Gresik Industrial Region). In addition to being an industrial city, Gresik has a lot of pesantrens (Muslim boarding schools) and religious tourist destinations that attract many tourists, especially the religiously motivated visitors. Islamic religious tourist destinations in Gresik Regency spread across the region, including Sunan Giri and Maulana Malik Ibrahim tourist sites which are widely known as saint tourist destination with thousands of visitors each day.

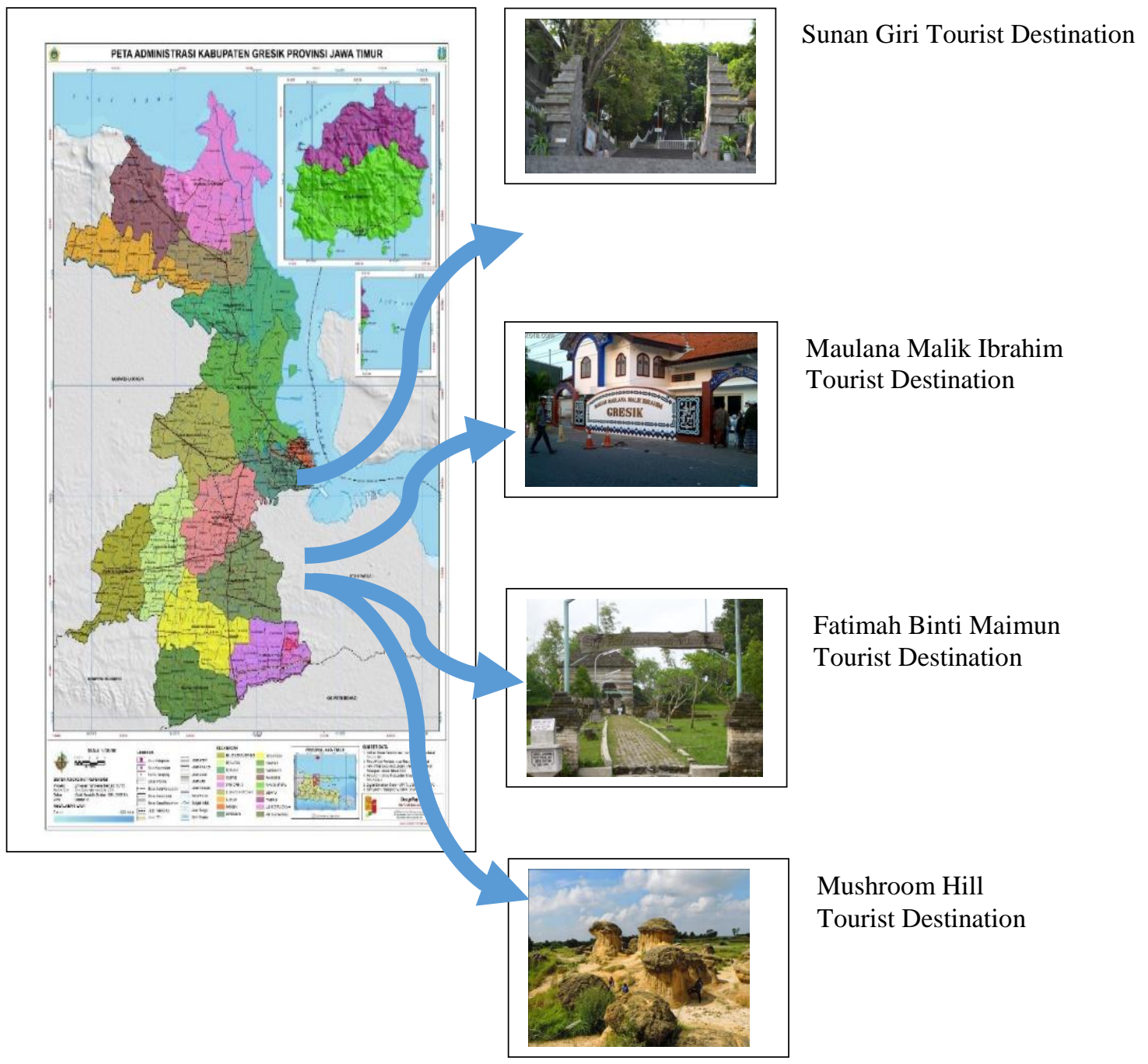

Picture 1: Tourist Destination Objects in Gresik Regency

\section{Current Condition of Surowiti Hill Religious Tourist Destination}

Surowiti Village is located in Panceng Subdistrict, located in the north side of Gresik Regency. Panceng Subdistrict is located at $\pm 3 \mathrm{~m}$ altitude above sea level and is about 40 $\mathrm{km}$ from Gresik City. Despite its distance from the city center, in term of tourism it is highly potential, with Dalegan White Sand Beach, Mushroom Hill, and Surowiti Hill. Surowiti Hill is a small village located on a hill of about 5 ha, altitude $260 \mathrm{~m}$ above sea level, with about 200 families. It is located on a steep hill connected with an asphalt road plus a 300-step stair. 


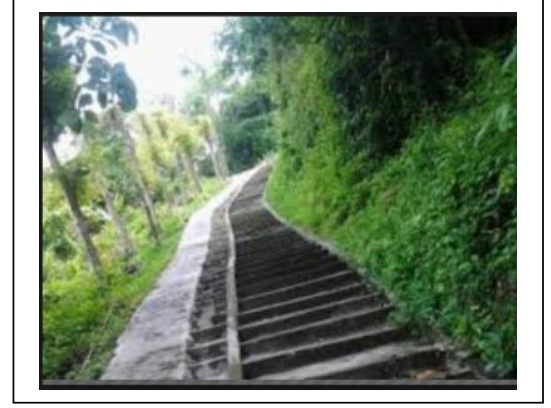

300 steps as an alternative to get to Surowiti Village settlement

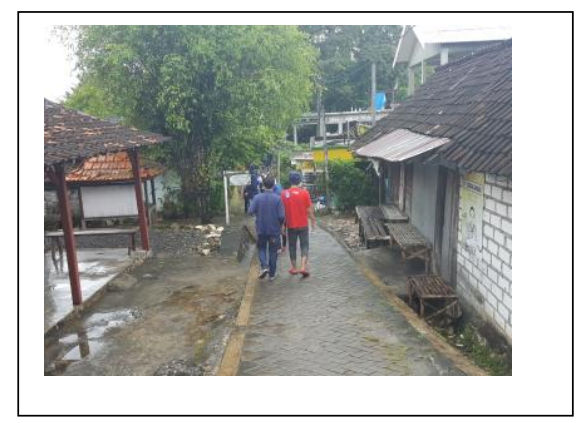

The asphalt road passable by motor vehicles to Surowiti Village

Picture 2: Surowiti Village Current Condition

Surowiti Hill offers seven tourist destinations in various locations, which fall into the categories of religious tourism and natural tourism. The religious tourist destinations include Sunan Kalijaga Tomb, Mbah Singo Tomb, Mpu Supa Tomb, and Raden Bagus Mataram Tomb, whereas the natural tourist destinations comprise of Langsih Cave, Macan cave, and Lumbung Cave.

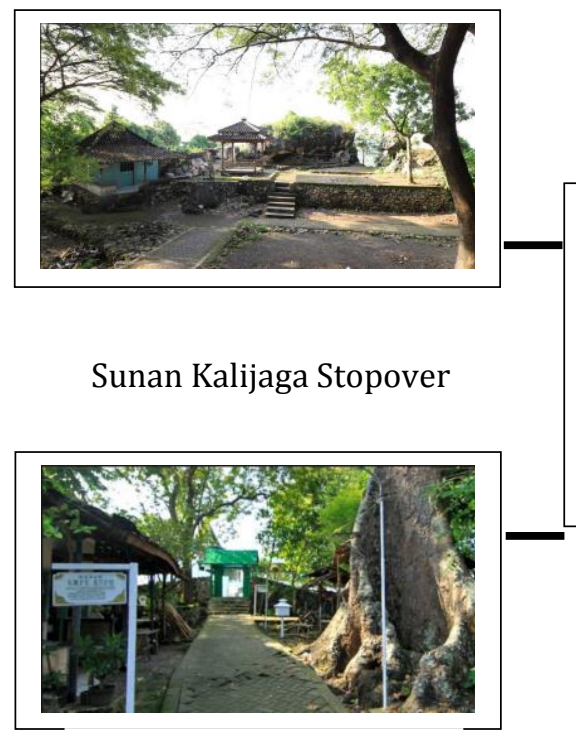

Empu Supa Tomb

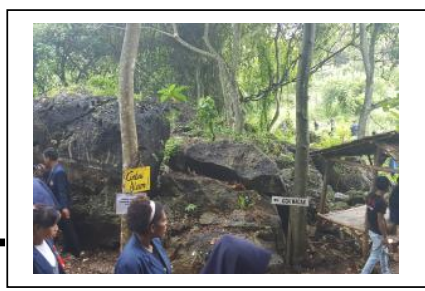

Macan Cave

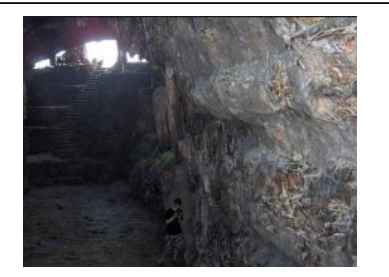

Langsih Cave

Picture 3: Some Tourist Destination Objects in Surowiti

With its various tourist destinations, Surowiti Hill has been considered highly attractive for tourists. The data collected by the management of the place, namely Kelompok Sadar Wisata Desa Surowiti indicate that the number of visitors keep mounting each year. However, the escalating number of visitors is not well supported with satisfactory equipment and infrastructure, indicated primarily with the lack of clean water and inadequate waste management.

Based on a survey that the researcher made, clean water is rare in this place. To fulfil everyday consumption of clean water, the Surowitans have to go down to a well on the foot of the hill. Sanitation condition is similar to that of the clean water: there is only one public bathroom available in the area. Drainage condition in the village is physically 
poor and not well integrated between houses, which results in dirty and messy environment.
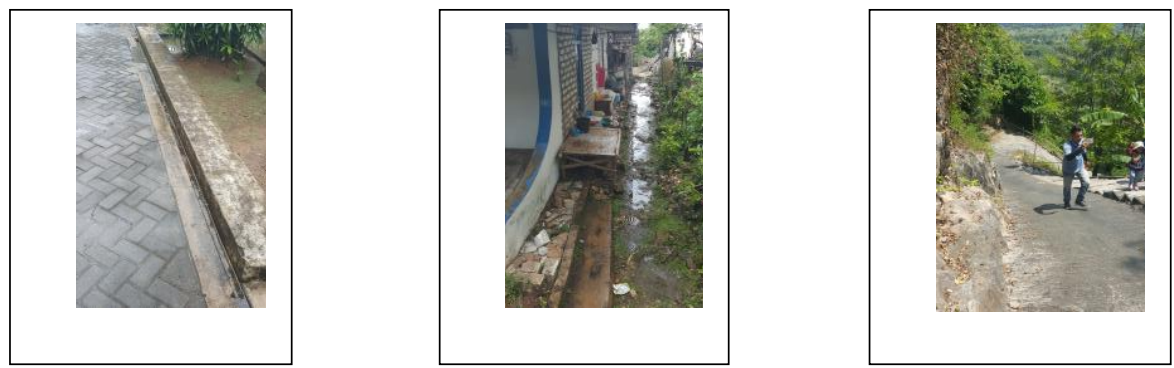

Picture 4: Drainage condition and roads in Surowiti Hill

Waste management is another problem in Surowiti Hill. Each family is responsible for their own waste, yet there is still neglected waste both from household and visitors. Public transportation is inadequate. Both public buses and special tour buses cannot get to the destination, resulting in held back visitors. Syafik (2012) estimates there are about 100 held back visitors per week based on the assumption that in a week in average a motor cycle can carry two people, a car five people, and big vehicles such as a bus can carry 50 people.

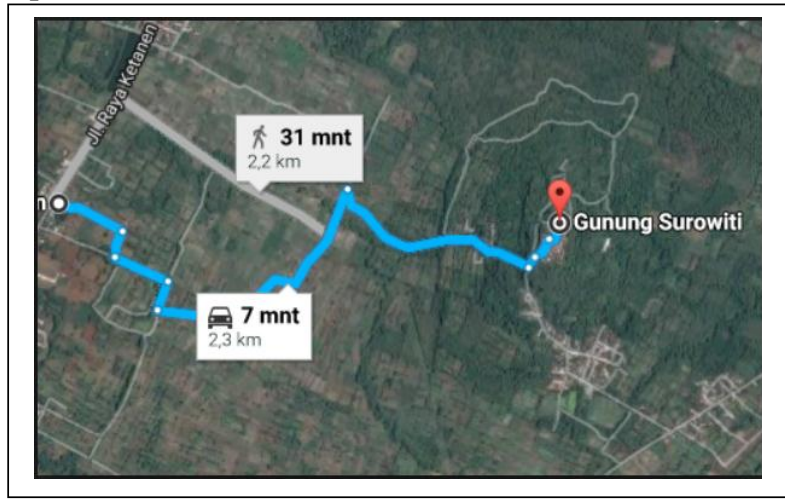

Picture 5: Map of location distance of Surowiti Hill from Gresik-Tuban main road

Kelompok Sadar Wisata Desa Surowiti also states that the number of visitors differs greatly among the various destinations of Surowiti Hill. Lingsih Cave enjoys the most visitors, and there is even a destination on Surowiti Hill complex which suffers from lack of visitors.

Internal and External Factors Strategy Analysis of Surowiti Hill Development in Panceng Subdistrict, Gresik

To analyze internal and external factors strategy analysis of Surowiti Hill development value multiplication and rating from primary data were used. The result from IFAS and EFAS matrix was then ranked and used to formulate development strategy of Surowiti Hill religious tourism as shown in Table 1 below: 
Table 1: Strategy Determination SWOT Matrix

\begin{tabular}{|c|c|c|}
\hline & $\begin{array}{l}\text { STRENGTHS (S) } \\
\text { 1. Religious tourist } \\
\text { destination proven by } \\
\text { Sunan Kalijaga Stopover } \\
\text { and some other Islamic } \\
\text { leader tombs in Gresik } \\
\text { 2. Beautiful views of hills } \\
\text { and some karts caves } \\
\text { 3. Boost economy of } \\
\text { surrounding residents }\end{array}$ & $\begin{array}{l}\text { WEAKNESSES (W) } \\
\text { 1. Lack of clean water } \\
\text { 2. Sanitation problem, } \\
\text { such as drainage and } \\
\text { waste } \\
\text { 3. Lack of fund to develop } \\
\text { supporting equipment } \\
\text { and infrastructure }\end{array}$ \\
\hline $\begin{array}{l}\text { OPPORTUNITIES (O) } \\
\text { 1.Gresik as a santri city and } \\
\text { is famous for its religious } \\
\text { tourism and Muslim Saint } \\
\text { tourism in East Java } \\
\text { 2.Famous tourist } \\
\text { destinations near Surowiti } \\
\text { Hill have so far attracted } \\
\text { many visitors, such as } \\
\text { Mushroom Hill and } \\
\text { Dalegan Beach } \\
\text { 3.Participation of Sadar } \\
\text { Wisata community in } \\
\text { managing Surowiti Hill }\end{array}$ & $\begin{array}{l}\text { (S-O) } \\
\text { Reinforcement of religious } \\
\text { tourism concept in } \\
\text { Surowiti Hill (IFAS - EFAS } \\
\text { matrix result 3.03) }\end{array}$ & $\begin{array}{l}\text { (W-O) } \\
\text { Intensify community } \\
\text { participation through } \\
\text { local government and } \\
\text { private sectors support in } \\
\text { managing Surowiti Hill } \\
\text { (IFAS - EFAS matrix } \\
\text { result 2.31) }\end{array}$ \\
\hline $\begin{array}{l}\text { THREATS (T) } \\
\text { 1.Rapid development of } \\
\text { industrial regions in Gresik } \\
\text { proven by the increasing } \\
\text { numbers of factory } \\
\text { buildings which have } \\
\text { reached Gresik City } \\
\text { suburbs } \\
\text { 2.Bad attitude visitors who } \\
\text { scribble on trees or rocks, } \\
\text { and who litter } \\
\text { 3.Landslides or erosion } \\
\text { which might happen to the } \\
\text { existing steep banks }\end{array}$ & $\begin{array}{l}(\mathrm{S}-\mathrm{T}) \\
\text { Implement strict } \\
\text { regulations to industries } \\
\text { and tour organizers as well } \\
\text { as visitors by local } \\
\text { government in Surowiti } \\
\text { Hill in Gresik Regency } \\
\text { (IFAS - EFAS matrix result } \\
2.30 \text { ) }\end{array}$ & $\begin{array}{l}\text { (W-T) } \\
\text { Improving the quality of } \\
\text { supporting equipment } \\
\text { and infrastructure of } \\
\text { Surowiti Hill (IFAS - } \\
\text { EFAS matrix result 1.58) }\end{array}$ \\
\hline
\end{tabular}

Source: Analysis Result, 2018

\section{Surowiti Hill Religious Tourism Development Strategy in Panceng Subdistrict, Gresik}

1. Reinforcement of religious tourism concept in Surowiti Hill, Gresik

There are a lot of interesting tourism potentials in Surowiti Hill that can be visited and developed by Gresik Regency local government. In addition to preserving tourist destinations left by our ancestors in the forms of tombs and other relics and natural views of karts caves in Surowiti Hill, it also functions as supports on Muslim saints' tourism and natural tourism which already exist in Gresik. Moreover, it 
boosts and strengthens surrounding resident's economy. There has to be serious efforts in preserving tourist destinations in Surowiti Hill by implementing religious tourism concept as part of the implementation and development of legitimate tourism which is becoming more and more popular for local as well as international tourists in Indonesia. This religious tourism concept reinforcement requires good cooperation among local community and Gresik Regency Government as well as supports from private sectors - especially industries in Gresik. All these stakeholders play an important role in developing religious tourism in Surowiti Hill.

2. Intensify community participation in managing Surowiti Hill

Intensifying surrounding community participation is an approach in managing a tourist destination site and it takes knowledge and awareness of the community itself. Continuous regeneration in managing the sites is also paramount if Surowiti Hill were to last longer. Local government participation is also very important in to avoid problems that might arise in managing and developing the existing religious tourist destinations.

3. Implement strict regulations to industries and tour organizers as well as visitors by local government in Surowiti Hill in Gresik Regency

Strict regulations for industries and housing entrepreneurs in Gresik are highly needed to limit the expansion of industrial factories and housing in the suburbs. The expansion will result in not only reducing tourism potential in Gresik Regency, but also in destroying the existing environment. In addition, regulation is also paramount for tour organizers and visitors to preserve environment in the vicinity of the tourist destinations.

4. Improving the quality of supporting equipment and infrastructure of Surowiti Hill

Surowiti Hill religious tourism region needs improvements and development in its supporting equipment and infrastructure. The existing equipment and infrastructure are inadequate and dysfunctional. Road infrastructure is quite good, but other infrastructures such as clean water and sanitation are bad. Improvement and development of infrastructure are needed to provide community as well as visitor comfort and to add to the appeal of the existing tourist destinations.

\section{CONCLUTION}

The formulation of strength, weakness, opportunity and threat factors in determining Surowiti Hill religious tourism development strategy helps describing or supplying information on the current condition which can be improved or those that will obstruct the development of Surowiti Hill religious tourism in Panceng Subdistrict, Gresik.

Surowiti Hill religious tourism is a tour complex which consists of some ancestors' inheritance in the form of relics and tombs of Islamic leaders. Surowiti Hill complex with its religious tourism aims to fulfil human's spiritual need to boost their faith by visiting religious sites, and at the same time visitors can enjoy beautiful scenery of Surowiti steep hills.

The reinforcement of religious tourism concept is part of Surowiti Hill development strategy as a support of Muslim-friendly tourism in Gresik. This will propel community's economy in the vicinity of the tourist destinations. This concept needs support from local residents, government as well as private sectors in Gresik in implementing regulations of tour management and environment preservation. Moreover, support from all stakeholders is needed to improve equipment and infrastructure in developing Surowiti Hill as a tourist destination, which consists of nature potential and well 
preserved ancestors' inheritance, especially in developing its religious tourism potential.

\section{DAREFERENCE}

[1] Anwar, M. F., Hamid, D., Administrasi, F. I., \& Malang, U. B. (2017). MASYARAKAT SEKITAR ( Studi pada Kelurahan Gapurosukolilo Kabupaten Gresik ). Jurnal Administrasi Bisnis (JAB)|, 44(1), 186-193.

[2] Barat, S. (2015). Persepsi Masyarakat Jakarta Terhadap Islamic, 1(1), 61-72.

[3] Battour, M., \& Ismail, M. N. (2016). Halal tourism: Concepts, practises, challenges and future. Tourism Management Perspectives, 19, 150-154. https://doi.org/https://doi.org/10.1016/j.tmp.2015.12.008

[4] Cetin, G., \& Dincer, M. Z. (2016). Journal of Tourismology, Vol.2, No.1 Muslim friendly tourism (MFT): A discussion Gurel Cetin 1 (Istanbul University) Mithat Zeki Dincer 2 (Istanbul University). Journal of Tourismology, 2(1), 65-67. Retrieved from http://dergipark.gov.tr/download/issue-file/3194

[5] Firdausia Hadi and M. Khoirul Hadi al-Asy Ari. (2017). KAJIAN POTENSI DAN STRATEGI PENGEMBANGAN WISATA PANTAI SYARI'AH (Studi di Pulau Santen Kabupaten Banyuwangi). Jurnal Manajemen Dakwah, 3(2), 99-166.

[6] Mahasiswa, S., Geografi, P., Ilmu, F., Surabaya, U. N., Ita, D., Zain, M., \& Kes, M. (n.d.). KABUPATEN GRESIK Rauf Ade Arief Abstrak.

[7] Supriharjo, Rimadewi (2013). Diktat Metodologi Penelitian, ITS Surabaya. 